\title{
Developing an integrated heritage management approach: the case of Hearne, Texas
}

\author{
R. Rabady ${ }^{1} \&$ T. Jamal ${ }^{2}$ \\ ${ }^{I}$ Department of Architecture, Texas A\&M University, USA \\ ${ }^{2}$ Department of Recreation, Park and Tourism Sciences, \\ Texas A\&M University, USA
}

\begin{abstract}
This study addresses integrated planning and management in rural Texas communities. While these communities have numerous valuable cultural resources, they often lack economic and technical resources for preservation and sustainable tourism development. This paper presents the results of a community-academic partnership to develop an inventory of historic and community resources plus a spatial database. The inventory database was developed to be compatible with that used by the state agency for historic preservation - the Texas Historical Commission (THC). The results were used to create an interactive database of cultural and tourism resources using Geographic Information Systems. An integrated approach to Historic Preservation and Heritage Tourism planning as developed in this project involves integrating across local interests and sectors, as well as between federal, state (regional) and local levels. Working with the local NGO and city council plus with the THC was critical to enable capacity building and continuity in the planning process. The information base has been actively used to initiate a series of planning and preservation activities aimed to improve the town's eligibility for financial and technical aid related to historic preservation and heritage tourism development. This project corroborates the need for a strategic framework that integrates historic preservation and heritage tourism planning. The challenge of addressing the diverse cultural heritage of communities like Hearne is also addressed briefly in the paper.
\end{abstract}

Keywords: integrated heritage management, sustainable development, historic preservation, heritage tourism, community involvement, historic site inventory. 


\section{Introduction: sustainability and 'heritage management'- the challenge}

The concept of "sustainable development" was introduced widely into business and economics through the Brundtland Commission's report "Our Common Future" (WCED [24]). Although the concept has been mostly used in relation to ecosystems and natural environment, recent efforts have attempted to apply it to the built environment and incorporate social and cultural aspects for "sustainable tourism" (Inskeep [12], McIntyre et al [15]). Attempts to control the impacts of mass tourism and apply sustainable development to heritage settings fostered the emergence of the 'integrated heritage management' (Orbasli [18], Hall and McArthur [8, 9], McKercher and Du Cros [16]). Integration as used by these authors is intended to recognize the need to balance heritage conservation (a term synonymous with historic preservation in the US) and heritage tourism development.

However, sustainability has been approached by the tourism industry primarily through marketing planning and visitor management-actions are driven by organizational interests focused on economic and profit motives (Fyall and Garrod [5]). On the other hand, heritage preservationists are concerned primarily with the conservation of built heritage resources. Tourism planning and heritage management appear fragmented rather than interdependent, due to disciplinary isolations and different (or divergent) interests. New mechanisms and approaches are desperately required in order to integrate historic preservation and heritage tourism, and develop effective management approaches and tools for sustainability of historic and cultural heritage environments (Carter et al [2]). This chapter offers a theoretical and practical effort to address some of these issues. We describe here a heritage inventory system and process that facilitates an integrated approach to heritage management in the rural community of Hearne, Texas.

\section{Sustainable heritage management- points of integration}

In their book "Cultural Tourism: The Partnership Between Tourism and Cultural Heritage Management" (McKercher and Du Cros [16]) point out that tourism and heritage conservation tend to evolve independently, using differing ideologies and concerns. They differ in their goals, objectives, usability of the resources, targeted users, and key stakeholders. Yet, each sector has developed a strategic method for managing the heritage. A historic preservation planning process is defined by the National Park Service (NPS) in the U.S. as "a rational systematic process of gathering and analyzing information and projecting preservation action into the future" (NPS [17]). The process is advised to flow through five stages (White and Roddewig [23], Facca [3], NPS [17]). The first is a preparatory stage to assess existing conditions by creating an inventory. Exhaustive guidelines are provided by the NPS for conducting a local survey to identify significant historical properties (NPS [17]). The second stage is to create an evaluation system for ranking the significance of a community's tangible 
(built) heritage based on its historical or architectural importance. Designated properties should be curatorially managed as a third stage. The last two stages include implementation of preservation plans and then interpreting and representing them for tourism. This is a rational, objective, scientific planning approach that focuses on site-related built aspects and says little about the cultural values or voices of those whose heritage or space is being inventoried.

Strategic process issues, on the other hand, have been extensively addressed in community-based tourism studies (Hall [10]). Stakeholder involvement is recommended at every phase of the strategic planning process: getting the community ready for developing tourism (includes developing a community vision, resource inventory), environmental scanning and assessment, developing goals and strategies; action planning and implementation; monitoring (requires indicators), evaluation and plan adjustment (Jamal and Getz [13]). Moreover, social and cultural impacts have to be considered for sustainable tourism development (Jamal and Tanase [14]).

Though historic preservation planners and tourism planners tend to operate autonomously, they both require an inventory at the early planning stages, Table 1. Historic preservationists survey historical assets and heritage tourism specialists assess the diverse resources that could serve tourism development (including cultural aspects such as festivals, foods and ethnic art). Sustainability oriented planning, we argue, requires an inventory tool and process that bridges historic preservation and heritage tourism development for integrated heritage management. It should link physical/built historic sites and properties, cultural heritage and tourism resources, and should facilitate planning and communication between tourism planners and heritage managers at the local, regional and national levels. And it should be an easy to use and affordable planning tool, so that rural communities like the one we describe below can afford to undertake sustainability-oriented tourism planning!

Table 1: $\quad$ Historic preservation and heritage tourism planning.

\begin{tabular}{|l|l|l|}
\hline \multicolumn{1}{|c|}{$\begin{array}{c}\text { Planning } \\
\text { Stages }\end{array}$} & $\begin{array}{c}\text { Historic Preservation } \\
\text { Planning (some key activities) }\end{array}$ & $\begin{array}{c}\text { Heritage Tourism Planning } \\
\text { (some key activities) }\end{array}$ \\
\hline Stage one & Historic preservation inventory & $\begin{array}{l}\text { Community vision; develop } \\
\text { heritage tourism inventory }\end{array}$ \\
\hline Stage two & Evaluation of historical assets & Env. scanning and assessment \\
\hline Stage three & Developing preservation plans & Develop goals and strategies \\
\hline Stage four & Curatorial management & Implementation of strategies \\
\hline Stage five & Presentation and Interpretation & Evaluate, Monitor, Adjust \\
\hline
\end{tabular}

Coordinating heritage management through the different levels (local, regional, state, national and global) and different scales (site level, destination and regional) is crucial to managing development impacts and striving for sustainable tourism. In other words, tourism planning should be approached 
using systems thinking, incorporating the demand and supply sides of tourism, as well as external factors (Gunn and Var [7]). Farrell and Ward [4] argued tourism system operated in a 'panarchy' of complicated nonlinear systems, requiring integration and interaction between sectors, scales, levels, and disciplines, of course with the participation of the communities.

In Texas, for instance, the Texas Historical Commission (the State Historic Preservation Office) is officially mandated for managing historic preservation. It also assists with associated heritage tourism aspects since it is one way to fund the economic needs of historic preservation. In order to facilitate coordination of the historic preservation and heritage tourism efforts between the three levels, the agency created the Community Heritage Development Division. The division includes four programs. The Heritage Tourism Program includes the Texas Heritage Trails Program, which is a regional initiative for encouraging regional development of heritage tourism. The other three programs were designed to operate on a local base. The Certified Local Government (CLG) program is administered in cooperation with the National Park Services, and is aimed to assist communities to preserve their historical properties. The Main Street Program is affiliated with the National Trust for Historic Preservation to assist communities in revitalizing their downtown areas. The Visionaries in Preservation Program is a recent initiative of the THC to facilitate communitybased preservation planning (THC [21]). Although the four programs have different conditions of application, they are structured to provide communities with technical, financial and marketing assistance to build local capacity and coordinate their heritage management efforts with regional and state level initiatives and agencies.

The value of utilizing an inventory database as an integration tool between sectors, levels and scales can be increased through associating it with Geographic Information Systems (GIS) tools. GIS enhances operational management capability because it provides accurate information that can be effectively communicated and rapidly exchanged between different users (Gillings and Wise [6]). The field of Cultural Resources Management (a surrogate name for Historic Preservation in the US) uses GIS technology for surveying, inventorying and cataloging information based on the architectural and historical characteristics of the assets on site (Box [1]). GIS is also used as a spatial management tool in tourism to aid in collecting, analyzing and representing information, as well as to facilitate participatory processes in heritage management (Hasse and Milne [11]).

Based on the above approach, we undertook a rural community project in Hearne, Texas, where we developed a Historic Preservation inventory database. An additional team member (Jitender Ramchandani, a graduate student in Urban Planning) helped to develop a tourism inventory framework and a spatial database based on the HP inventory using ArcMap 9.0. The section below focuses on the HP inventory and the integration of preservation and tourism at this early planning stage. The aim was to enable the community to develop an integrated heritage management approach to preservation and development of its historic and cultural heritage resources. 


\section{The rural community of Hearne, Texas}

Hearne is marketed as the Crossroads of Texas. The largest community in rural Robertson County, its development is rooted in two prominent Frontier activities: railroad and agriculture (primarily cotton). Its history dates back to 1835 when a prominent adventure-seeking Tennessean, Sterling C. Robertson, obtained a land-grant from the Mexican Government in Texas. In 1852, the Hearne family arrived from Alabama to Wheelock. They were plantation owners, possessing capital, experience and a sizeable labor force of primarily Black indentured workers. To market his cotton, Christopher Columbus Hearne offered a land donation to the Houston and Texas Central Railroad to route the railroad by his land. After his death in 1868, Hearne was established as a railhead. The 700-acre town-site had a Central Business District (CBD) that included hotels, saloons, gambling halls, and churches, photo 1 . A residential area emerged near the CBD with churches and schools. In the 1870s, and with the establishment of the second railroad in Hearne (the International and Great Northern Railroad), the CBD was moved a short distance to the intersection of the two rail crossings. In 1901, the Hearne Railroad Depot was built and the city flourished, photo 1.
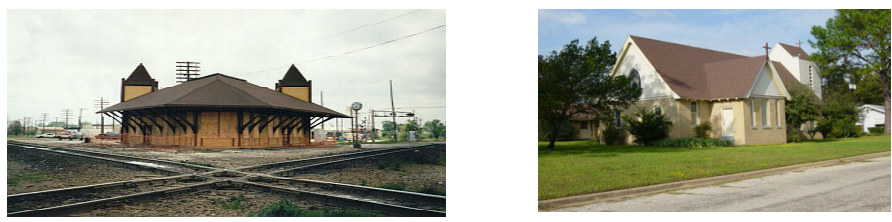

Photo 1: Hearne heritage resources; Hearne Depot (left) and Episcopal Church (right).

In 1942, Camp Hearne was established to house over 5,000 prisoners of war, primarily German. In 1944 the camp also provided a central mail service for all German POWs within the United States. Today, Hearne's population is around 5,000; close to $40 \%$ are African American (Black), about 30\% Anglo (White), and $30 \%$ Hispanic and other. New land uses include parks and playgrounds, clubs, churches and schools that serve different ethnic groups. Hearne's rich and diverse history manifested in historic sites and built structures in and around the City. Over time, lacking established planning and zoning regulations or adequate resources to protect a number of important sites, the historic assets of this city has suffered. A number of buildings have been destroyed or have deteriorated badly. The decline of agriculture and railroad activities has hit the community badly, leading it to seek diversification. Heritage tourism is an important agenda item. A collaborative project for developing a historic preservation and heritage tourism information base was commenced in September 2004. It was initiated by a local non-profit group Roll Call (Friends of Camp Hearne), with the support of the town's public sector, and assistance from faculty and students at Texas A\&M University. Over the period of 16 months, several initiatives were taken to assist the city in documenting and gathering heritage and tourism-related information on community resources (Rabady and Jamal [19], Rabady et al [20]). 


\section{Developing a historic preservation-and tourism information base for Hearne}

\subsection{Scope of the heritage preservation inventory}

The legal boundaries of the city were used as a base for the scope of our inventory, Fig. 1. Exceptions were made to include external sites that have historical significance connected with the history of Hearne (cemeteries for example) or historic or tourism-relevant properties that are owned and controlled by the City of Hearne (e.g., Camp Hearne; the Municipal Airport).

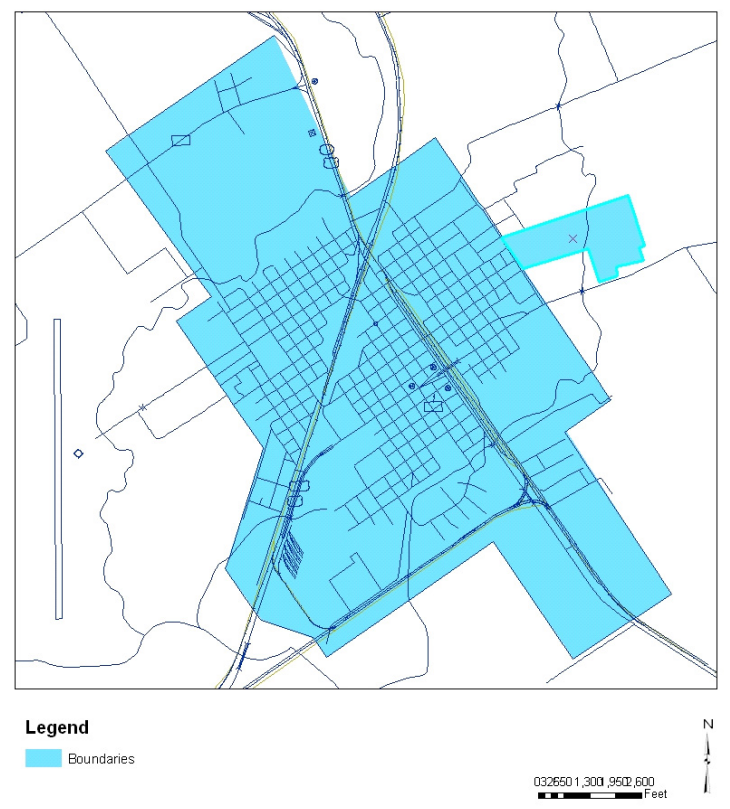

Figure 1: Legal boundaries of Hearne.

\subsection{Historic preservation inventory}

The historic preservation inventory conducted for Hearne includes the identification of historical assets (buildings, structures and sites) and their characteristics as well as identification of present conditions of these properties. Surveying the historical properties in Hearne was done in two stages. Stage one involved gathering information for defining the historical significance of the city. In Stage Two, the information was compiled into a database using Access database software. This was developed specifically to ensure compatibility with the historic inventory database used by the Texas Historic Commission. The State's database was too complex for the needs of this rural community, but we had to ensure that the database we developed was both user-friendly, affordable 
to maintain, and still compatible with the State database so that evaluations and applications for historic designations and funds could be facilitated.

\subsubsection{Stage One: gathering the information}

Gathering the information in the first stage evolved in two phases. The first phase was a reconnaissance inventory to help build preliminary knowledge about Hearne's history, its significant historical properties and their locations. Instrumental to this stage was meeting with and understanding residents' views and opinions about historic preservation and heritage tourism development in Hearne. Sources used for conducting the reconnaissance inventory included:

- Secondary data sources including maps, books, newspaper articles, brochures, Hearne's City Hall archives, County tax rolls, aerial photographs, old photos, published and archived research on Camp Hearne (Waters [22]).

- Sanborn maps that depict the evolution of Hearne's historic properties from 1885-1925.

- Face-to-face meeting with community leaders and residents: religious leaders, lawyer, local school officials, community volunteers (e.g., local fire station volunteers), historical property owners, City Council and local agency members, NGO's, business owners, and residents who had made significant efforts to preserve local landmarks. Our efforts to meet with the diverse ethnic constituents of Hearne were hampered by lack of resources and time, and while we met with a few, our primary interactions were with the Anglo (White) community members.

- A community questionnaire distributed by hand to key stakeholders groups and printed in a mail-back form in the local newspaper. It contained structured and open-ended questions about historic preservation and heritage tourism development in Hearne; plus sought demographic information.

The above information sources were invaluable for building knowledge about Hearne's historical significance and for orienting the second phase: conducting an intensive inventory. This involved a detailed field survey of historic sites and properties. It focused on two kinds of historical resources: significant individual landmarks scattered within and around the city boundaries, plus the Historic Downtown Area that contributes to the community's image and sense of place.

\subsubsection{Stage Two: compiling and arranging the information}

Historical properties were categorized into the "Historic Downtown Area" and the individual "Landmarks". Each category has several sections. The downtown area was classified based on street names (Magnolia, Fourth and Third Streets) and the landmarks according to their uses (cemeteries, commerce, culture, domestic, education, government, industry, and social). Three techniques were used to describe each historical property: tables illustrating main characteristics according to items required by the THC's survey form; maps to show locations; and figures to show the property's image. This resulted in documenting 109 historical properties (fifty-six in the downtown area). Eighteen have State historic designations and one has both State and National Register designation. Twelve other landmarks have Texas Historic Commission Markers, including the Hearne Railroad Depot, Hearne City Hall, Camp Hearne, Hearne's first 
school (now a residence), and three churches located in the downtown area. One other landmark is a Texas Historical Medallion, and four are in the Texas Historic Commission Survey.

\subsection{Developing a tourism inventory}

A fully developed tourism inventory requires addressing both the demand and supply sides of tourism. The town did not have visitor statistics or a full inventory of community, tourism and hospitality resources. With so little to start with, and a very slim project budget, it was decided therefore to set up a general tourism inventory structure using Access software. In order to facilitate collecting data on each supply-side variable in the tourism inventory, short online forms for gathering and entering data online were created in HTML format. The goal was to provide a set of basic tools that the community could use over time to develop a Tourism Resource Database (TRD). A small amount of primary data on food services was collected along with some secondary data on accommodation and supporting facilities. This information was entered into the tourism to illustrate portions of the filled-in inventory. If Internet connectivity is an issue as has been the case in Hearne, hard copy questionnaires can be the predominant instruments for data collection.

\subsection{Results: creating the HP-HT information database}

Once the inventories were completed, the team started to work on creating spatial database (maps) using ArcMap 9.0. A geodatabase was commenced using different files such as parcel map, road maps, and topography as shown in Rabady et al [20]. A great deal of time and efforts was expended in cleaning and compiling the data into usable form (far more effort than originally anticipated). Maps that spatially record the location and characteristics of the cultural and tourism resources were prepared, Fig. 2.
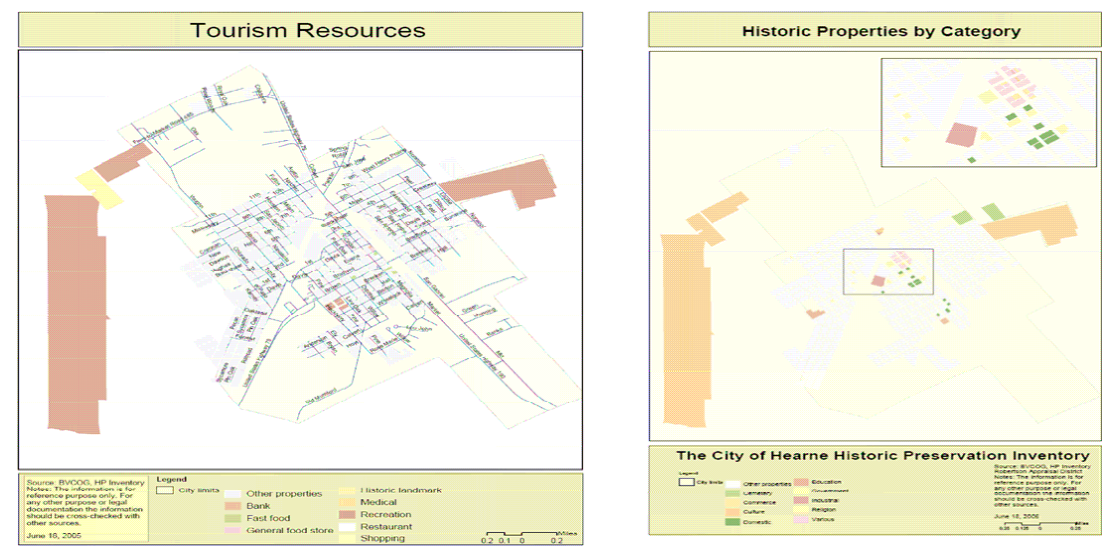

Figure 2: Hearne's tourism and historic resources. 


\section{Towards integrated heritage management}

Our inventory shows that Hearne currently has one hundred nine historical landmarks. They reflect a historical richness and active community efforts to protect and preserve it. The community's economic problems (due to decline in agriculture and railroad activities) necessitate an aggressive plan for preserving these special places and generating revenues through sustainable use. While Hearne has a dedicated and civic-minded group of residents, volunteers and community leaders, economic hardships make it immensely difficult to invest necessary funds into historic preservation and planning. Hearne has completed an important step in preservation planning by completing developing a historic preservation inventory and commencing to compile information for a tourism inventory. Since the inventory was completed, it has been enhanced by an architectural rendition of the historic properties (Rabady and Jamal [19]), and has been used for several other planning activities such as development of new visitor brochures (e.g., for Camp Hearne), and development of sample ordinances for historic preservation related scenarios (Rabady et al [20]). A number of local residents have expressed strong interest in learning more about their own community through the inventory as well.

Joint partnerships are needed both within the community and with others regionally to protect, sustain and market the town's built and cultural heritage. The inventory will assist Hearne to engage in cooperative marketing with other communities in the Texas Brazos Trail Region (a regional initiative). Locally, the Visioning in Preservation Program (a Texas Historic Commission program) will also help communities to develop a long-term preservation strategy and resident responsive heritage tourism.

Documenting the community's diverse cultural heritage through direct resident narratives is an important future step, since the HP inventory documents its built heritage but not the narratives and oral histories of the diverse cultural and ethnic groups linked to its historic sites. A comprehensive built and cultural heritage inventor will prepare the community well to participate in the next steps of preservation planning. Empowering the community to take charge of protecting and sharing its historic and cultural resources is crucial, especially when the assets being considered for tourism are related to "heritage", a notion that is often contested and highly political.

\section{References}

[1] Box, P., GIS and Cultural Resource Management: A Manual for Heritage Managers, UNESCO, Bangkok, 1999.

[2] Carter, R., Baxter, G. \& Hockings, M., Resource Management in Tourism Research: A New Direction? Journal of Sustainable Tourism, 9 (4), pp. 265- 280, 2001.

[3] Facca, A., An Introduction to Historic Preservation Planning. Planning Commissionaires Journal, 52, pp. 3-11, 2003. 
[4] Farrell, B. \& Ward, L.T., Reconceptualizing Tourism. Annals of Tourism Research, 31(2), pp. 274-295, 2004.

[5] Fyall, A. \& Garrod, B., Tourism Marketing: A Collaborative Approach, Channel View Publications: Clevedon; Buffalo, 2005.

[6] Gillings, M., \& Wise, A., GIS guide to good practice. Oxbow Books: Oxford, 1990

[7] Gunn, C., \& Var, T., Tourism Planning: Basics, Concepts, Cases, Routledge: USA, $4^{\text {th }}$ Edition, 2002.

[8] Hall, C. \& McArthur, S., (eds). Heritage Management in New Zealand and Australia, Oxford University Press: Oxford, 1993.

[9] Hall, M. \& McArthur, S., Integrated Heritage Management, Principles and Practice. Stationary office: UK, 1998.

[10] Hall, C.M., Tourism Planning: Policies, Processes and Relationships. Addison Wesley Longman: Harlow, 2000.

[11] Hasse, J \& Milne, S., Participatory Approaches and Geographic Information Systems (PAGIS) in Tourism Planning. Tourism Geographies, 7 (3), pp. 272-289, 2005.

[12] Inskeep, E., Tourism Planning: An Integrated and Sustainable Development Approach. Van Nostrand Reinhold: New York, 1991.

[13] Jamal, T. \& D. Getz., Collaboration Theory and Community Tourism Planning. Annals of Tourism Research, 22 (1), pp. 186-204, 1995.

[14] Jamal, T. \& Tanase, A., Conflict over the proposed Dracula Park location near Sighisoara, Romania: The Role of Sustainable Tourism Principles. Journal of Sustainable Tourism, 13 (5), pp. 440-455, 2005.

[15] McIntyre, G. with Hetherington, A. \& Inskeep, E. Sustainable Tourism Development: Guide for Local Planners. Madrid, Spain: World Tourism Organization, 1993.

[16] McKercher, B. \& Du Cros, H., Cultural Tourism-The Partnership Between Tourism and Cultural Heritage Management. The Hawrth Hospitality Press: New York, 2002.

[17] National Park Service (NPS), www.nps.gov/

[18] Orbasli, A., Tourists in Historic Towns-Urban Conservation and Heritage Management, E \& FN Spon: London and New York, 2000.

[19] Rabady, R. \& Jamal, T., Developing a Historic Preservation and Tourism Information Base for Hearne, Texas: Architectural Inventory, Texas A\&M University: College Station, 2005.

[20] Rabady, R., Ramchandani, J. \& Jamal, T., Developing a Historic Preservation and Tourism Information Base for Hearne, Texas, Texas A\&M University: College Station, 2005.

[21] Texas Historical Commission (THC), www.thc.state.tx.us/

[22] Waters, M., Camp Hearne, Texas: A German prisoner of War Cam during the Second World War, Online. http://nautarch.tamu.edu/anth/waters/

[23] White, B. \& Roddewig, R. Preparing a Historic Preservation Plan. American Planning Association: USA, 1994

[24] World Commission on Environment and Development (WCED), Our Common Future. Oxford University Press: Oxford, 1987. 